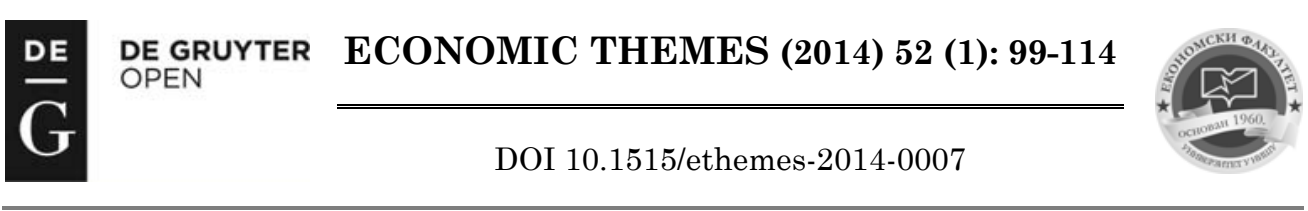

\title{
THE QUALITY OF FINANCIAL REPORTING IN THE REPUBLIC OF SERBIA
}

\author{
Tadija Đukić \\ University of Niš, Faculty of Economics, Serbia \\ $\bowtie$ tadija@eknfak.ni.ac.rs \\ Miloš Pavlović \\ University of Priština, Faculty of Economics Kosovska Mitrovica, Serbia \\ $\bowtie$ milos.pavlovic@pr.ac.rs
}

UDC

657.375

(497.11)

Review paper

Received:

09.01.2014

Accepted:

02.04.2014

\begin{abstract}
High quality financial statements should truly and objectively reveal the financial position, business results and changes of a business entity. Satisfied users of financial statements according to which they make decisions represent the best confirmation of high quality financial reporting. The paper deals with the conceptual framework of financial reporting and with an attempt to create unified and revised conceptual framework as a joint project by FASB and IASB. Moreover, it considers novelties that the framework brings. Also, the paper points to the current state in terms of financial reporting quality in the Republic of Serbia. Furthermore, the paper points to some shortcomings of accounting regulation at the national level as a prerequisite of high quality reporting. Finally, the authors propose certain measures and activities for enhancing financial reporting quality in the current economic and political conditions in the Republic of Serbia.
\end{abstract}

Keywords: financial reporting, revised conceptual framework, aims of reporting, qualitative characteristics, Republic of Serbia

\section{Introduction}

Financial reporting represents a very important segment of enterprise business. Its role consists of establishing stable and reliable infrastructure in communication between enterprise and the environment. Financial statements are an important source of information on transactions that enterprise has with environment, without which it is not possible to organize enterprise business 
and make correct decisions. According to the Framework for Preparation and Presentation of Financial Statements, the aim of financial statements is to present correctly and objectively the financial position, business results and change in financial position. If financial statements entirely meet this requirement, it can be said that they are of high quality.

By its very nature, financial statements are not only primarily directed to external users (investors, creditors, customers, state authorities, social community, etc.) but also represent reliable foundation for the management of enterprise as an internal user to do both the business analysis and decision making, including other purposes as well.

The quality of financial statements can be looked from the perspective of users in terms of their expectations, involving satisfying information need fulfillment or not.

We are of the opinion that the quality of financial statements is only valid to look from the perspective of the users of financial statements.

Over the years, the base of the users of financial statements has spread and their needs for information have increased. Business globalization has led to the possibility that the users of financial statements can be persons from different countries even continents, which conditioned the need for unified financial statements in order that users can interpret and analyze them. Also, the need for limiting the subjectivity in preparing and presenting financial statements appeared. Today, all this has led to the fact that the issue of financial reporting in many countries has been arranged by legal regulations and adequate professional regulation that is founded according to Generally Accepted Accounting Principles (GAAP). Aside from that, both leading FASB and IASB have developed own financial reporting frameworks. Hence, it may be concluded that the process of financial reporting, from the aspect of normative base, is highly regulated area.

The paper deals with conceptual framework of financial reporting, an attempt to make unified project by FASB and IASB as well as novelties this framework brings. Moreover, the paper reveals the current state in terms of high quality financial reporting in the Republic of Serbia and points to certain shortcomings of accounting regulation at the national level as a prerequisite of high quality financial reporting. Finally, the authors propose measures and activities for enhancing high quality financial reporting in the current economic and political conditions in the country.

\section{The Role of Financial Reporting}

Financial reporting implies reporting on the state, success, cash flows and decision-making for the purpose of securing information foundation for 
economic judging and making economic decisions by the users. The fundamental characteristic of financial reporting under contemporary conditions is the public interest. That is, stable growth and economic and social development are completely in the focus of what we consider the public interest. The condition for realizing the public interest is transparent financial reporting that should contribute to bridging the gap between what the user of financial statements expects and what financial statements provide. There is a general consent that financial reporting never has had its own objectives but that it is the precondition for market economy to function well. The impact of financial reporting on enhancing national economy is multiple and can be reflected in the following contributions:

- Enhancement of the financial system of a country, reduction of risk from financial crisis and their negative impact on the business of national economy,

- Increase in savings of population and economy,

- Increase in direct and indirect foreign investments,

- Easier access to bank credits,

- Good investment decisions made by investors, which has as a consequence better assets allocation,

- Better management performance assessment by shareholders,

- Integration enhancement at the national, regional and global level.

\section{Conceptual Framework of Financial Reporting for the Purpose of High Quality Financial Reporting}

Spreading the circle of the users of accounting information and growth of their information needs dictated the development of accounting reporting, which reflected in continual adjustment and improvement of procedures and means of collecting and presenting information.

The accounting practice does not develop in vacuum, isolated from the events in the environment, but to the contrary gives dynamic answers to macro and micro economic changes in political, fiscal and economic plan as well as trade conditions (Elliott and Elliott, 2011, p. 30).

In attempt to secure the same or similar approach to treating business events in different business activities and thus limiting the subjectivity, the issue of financial reporting today in the most of countries is arranged through legal regulations and/or adequate accounting standards, i.e. professional regulation. The mentioned regulation is grounded on generally accepted principles (Davidson, 1983, pp. 1-23) that are based on the principle of correct bookkeeping and balancing and express generally accepted rules of work reporting assumptions in a certain moment. 
Although the generally accepted accounting principles are modified in time and are supplemented in compliance with the changes in the environment and the growth of information demands on the side of the users of financial statements, the commitment to them is the precondition for transforming data of financial accounting of enterprise into reliable and valid financial statements.

Because of continual improvement of the practice of financial reporting and the attempt to create unified stance in solving the problem related to financial reporting, it have come to the development of theoretical framework of financial reporting known better as " conceptual framework". Thus, the two most influential world institutions, FASB (FASB-Financial Accounting Standards Board) and IASB (International Accounting Standards Board) have developed their own conceptual frameworks for financial reporting. FASB's conceptual framework is presented in a series of seven Statements of Financial Accounting Concepts while IASB's conceptual framework is presented in the document "Framework for Preparation and Presentation of Financial Statements".

FASB's conceptual framework (SFAC) was created in 1978 and has suffered many changes and amendments ever since. It can be presented in the following manner:

Table 1 FASB's Conceptual Framework for Financial Reporting

\begin{tabular}{|c|c|c|}
\hline $\begin{array}{l}\text { SFAC } \\
\text { number }\end{array}$ & Name & Acceptance Date \\
\hline 1 & The aims of financial reporting & November 1978 \\
\hline 2 & $\begin{array}{l}\text { Qualitative characteristics of accounting } \\
\text { information }\end{array}$ & May 1980 \\
\hline 3 & Changed with SFAC 6 & \\
\hline 4 & $\begin{array}{l}\text { The aims of financial reporting of non- } \\
\text { profit organization }\end{array}$ & December 1980 \\
\hline 5 & $\begin{array}{l}\text { Acceptance and measurement in financial } \\
\text { statements }\end{array}$ & December 1984 \\
\hline 6 & Elements of financial statements & December 1985 \\
\hline 7 & $\begin{array}{l}\text { Using information on cash flows and net } \\
\text { current value in accounting }\end{array}$ & February 2000 \\
\hline
\end{tabular}

Source: FASB: Statements of Financial Accounting Concepts.

IASB's conceptual framework deals with following issues:

- The aims of financial reporting,

- Qualitative marks of accounting information,

- Definition, recognition and measurement of elements out of which financial statements are built,

- Capital concept and investment manifestation. 
Since the 1980s of the last century when the regulation in this area started, numerous changes occurring in the environment have led to the need for certain changes in the present conceptual framework. These changes are related to the development of world financial market and appearance of new trade instruments, i.e. new modes of assets and liabilities. This has lead to bringing information needs of investors and creditors to the fore. Harmonization and standardization of financial reporting thus gained additional incentive and led to the Memorandum of Understanding between IASB and FASB in 2002. The appearance of new assets mode to the fore of new financial instruments has led to consideration and revision of valid rules for recognition and evaluation of assets and liabilities.

Revision of the conceptual framework as the foundation for creating international standards forced itself as inevitability. The revision of the current Conceptual Framework has the aim to examine each accounting principle, each assumption of financial reporting and each concept. The outcome of such consideration will be their retention, change or rejection. Both bodies for bringing the financial reporting standards started the joint project for their revision in 2004.

By means of revision two aims should be achieved:

- Alignment of the Framework for Financial Reporting brought by IASB with that brought by FASB.

- Improvement through eliminating inconsistency, contradiction and gaps that are present in the existing frameworks.

The project has been conceived to follow these 8 stages:

A) Aims and qualitative characteristics;

B) Definition of the elements of financial statements;

C) Evaluation;

D) Financial reporting elements;

E) Presentation and preparation;

F) Scope and purpose;

G) Application for non-profit organizations;

H) Etc.

In designing new Conceptual Framework several stages are engaged in a parallel manner. For now, only the stage A was completed in September 2010 while the stages B, C and D were being conducted at the same time. Currently, all the stages have been postponed. Considering that only the stage A was completed- The Aims and Qualitative Characteristics we will further examine the novelties that this stage brought. The stage A was completed on September 28, 2010 and then the Board published the Chapter 1-The Aims of General Purpose Financial Reporting and Chapter 3-Qualitative Characteristics of 
Financial Information within the Statement on the Financial Accounting Concept No. 8-The Conceptual Framework for Financial Reporting.

According to revised conceptual framework, the aim of general purpose financial reporting is to provide financial information on the economic entity which is useful to the existing and potential investors, creditors, lenders in making decisions on asset lending to entities (FASB, 2010). Aside from that, they are directed to users giving assets to reporting entity but they do not have the possibility to make the entity give them information necessary for making decisions on the investment. Consequently, the circle of users of financial statements was way to wider so that the users of financial information equally appeared, including current and potential investors, debtors, employees, suppliers, buyers, government and its agencies and other public.

Among the above definitions of the objectives of financial reporting, there are significant differences that will affect the regulation of other phases in the project of making a revised conceptual framework. These differences are related to (Škarić, 2011, p 34):

- the primary user group of financial statements and

- information that financial statements should provide to users.

The circle of users of financial statements that, in the previous framework was much wider, in revised was significantly reduced. Existing and potential investors, creditors or other creditors are indicated as the primary users of financial statements As we can see, there are no management and the government among them because, as stated in the framework, information useful for investors and creditors largely meet the information needs of other users, including managers. In addition, it is stated that the administration and the state have the power to request and receive from the reporting entity information tailored to their needs. Also, the financial statements may not provide all users the information they need, and therefore no information about the value of the reporting entity as a whole.

When talking about the quantitative characteristics of financial information, it should be noted that they are designed to require from the information such quality that will primarily serve current and potential investors, creditors and other creditors. Previous conceptual framework included as a basic quantitative characteristic of financial information the following:

- comprehension;

- relevance;

- trust and

- comparability.

Unlike the previous, the revised conceptual framework of basic quantitative characteristics includes only (IASB , 2010): 
- relevance, within which the materiality as a specific aspect of relevance is stated,

- credibility.

The additional characteristics of financial information that improve the previous two statements are the following (IASB , 2010):

- comparability and consistency,

- verifiability,

- timeliness and

- comprehension.

Relevance is the information characteristic that provides decision-makers with enough data to make decisions. As a secondary quality of relevant information, predictability and reversibility are listed. The financial information has the quality of predictability if it can be used by the users to predict future results. It should be noted that the financial information might not necessarily be predictions or forecasts to have a quality of predictability, but allow users to make them based on their forecasts and predictions. The financial information has the quality of reversibility when it provides feedback (confirmation or change) on the previous estimates. Predictability and reversibility as characteristics of financial information are related to each other and often the information that has the quality of predictability has the quality of reversibility as well. For example, information on income for the current year, which can be used as a basis for forecasting revenue in the coming years, also can be compared with the predictions of income from previous years and related to the current year. The results of these comparisons can help the user to correct and improve the very process and predictions (forecasts).

Information has the quality of materiality if its omission or misrepresentations may influence the economic decisions of users made on the basis of financial statements. Materiality depends on the size and nature of the omission or misstatement of the item being evaluated in the particular circumstances, so we cannot determine a unique threshold of materiality, i.e. the limit that the quality of information has pass in order for it to become materially important, but it depends on the situation.

The financial statements represent the company's operations in words and numbers. To be useful, the financial statements, in addition to relevance should be credible as well, that is to faithfully represent events that are contained in them. In order that the financial statement could be entirely credible, it must meet three conditions. It must be complete, neutral and compiled without errors (IASB, 2010). Of course, it is difficult to reach perfection, but it is possible to strive to maximize the above quality to the fullest extent possible. 
In order for a review to be complete, it is necessary to include all the necessary information to enable the user to understand the phenomenon which it represents, including the necessary descriptions and explanations. For example, a complete review of a group of assets will, as a minimum, include the characteristics of the group of assets, and an explanation of the numerical values of the group of assets (e.g., cost, price adjustments or fair value). For some things, the entire display may also require explanations of important facts about the quality and nature of the case, the factors and circumstances that may affect the quality and nature of the proceedings that led to a numerical interpretation.

Neutral review represents the review without bias in the selection or presentation of financial information and without an element of manipulation in order to present information in a different way than the actual situation. Neutral information is information that does not influence decision-making, on the contrary, the basic requirement is the relevance of the information to be used in business decision-making.

Truthful review, that is the credibility of information does not imply the accuracy of information in all aspects. Display without error means that there are no errors in the description of the phenomenon and the process that has been used to get this information (choice of collection methods and its implementation). In this context, the error does not imply perfect accuracy in all aspects.

Comparability and consistency, confirmability, timeliness and clarity are the qualitative features that enhance the usability of information that is relevant and faithfully represented (Stojanovic, 2012).

Business decision-making often involves making a decision between two or more alternatives, such as selling or keeping the investment, invest in one or the other company and the like. Thus, information about a reporting entity is useful when there is a possibility to compare it with the same or similar information of another reporting entity or the same entity but with the information from other periods. Comparability is a qualitative characteristic that enables users to identify and understand the similarities and differences between items. Unlike other quality characteristics, comparability relates to a comparison of an individual item.

Consistency, although it is related to the quality of comparability cannot be identified with it. Consistency refers to the use of the same methods for the same things, or from period to period within the reporting entity or in a period in more reporting entities. Comparability is the goal, and consistency allows achieving this goal. It should be noted that the same business event can faithfully be displayed in several ways, with the help of alternative accounting methods for the same business events, leading to reduced comparability. 
Verifiability as the quality of the information provides customers with information that faithfully represents the business event to which it refers. Verifiability means that more professional and independent observers could reach consensus, although it does not necessarily mean that the agreement is completely credible (Stojanovic, 2011). Confirmability (verification) of certain information or review can be direct or indirect. Direct verification involves checking a certain amount or a display through direct examination, for example, counting the money. Indirect confirmation means checking the inputs in the model, formula or other technique and calculating the output by using the same methodology. An example is checking the carrying value of inventory by checking the inputs (quantities and costs) and the calculation of the end period inventory using the same assumption of inventory flow (for example, using the FIFO method ).

Timeliness means that decision makers have the information before it loses the ability to influence decisions. If information is older, it loses its usefulness. However, some information can continue to be timely long after the close of the reporting period in order to assess trends.

Classifying and presenting information clearly and concisely provides the user with intelligibility of information. Intelligibility is the quality of information that enables users to understand its meaning, assuming that users are qualified and willing to study financial statements with due attention.

\section{The Current State of Financial Reporting Quality}

Striving for adapting the model of financial reporting in the Republic of Serbia to the international accounting model began in the mid nineties. Namely, at that moment the accounting profession gathered in the Federation of Accountants and Auditors of Serbia and supported by accounting academic circles, began to think about the possibility of the introduction of international accounting standards and strategies of adaptation to national accounting. In recognition of the need for uniform accounting language that will not be a barrier to inclusion into international financial markets, the Federation of Accountants and Auditors of Serbia in December 1998 adopted the direct application of International Accounting Standards (IAS )/International Financial Reporting Standards (IFRS) as the basis for the reporting of domestic companies. However, from the decisions made to the legal requirements for effective implementation of these standards, it's been a few years. In that period the accounting profession was introduced to the substance of IAS, the first steps of their translation as well as possibilities for their application. Numerous symposia organized by the Association of Accountants and Auditors of Serbia were supported by the acquisition of general insight about the need and importance of IAS for the Republic of Serbia. Law on Accounting and Auditing 
of the year 2002 (Official Gazette of FRY , No. 71/ 02) introduced the obligation of companies to apply IAS / IFRS in recognition and valuation of accounting positions and the same solution was retained in subsequent legal solutions in the areas of accounting and financial reporting .

In Serbia, in 2013, two laws were passed in the area of financial reporting: the Accounting Act (Official Gazette of RS, No. 62 /2013) and the Auditing Act (Official Gazette of RS , No. $62 / 2013$. We will point to some shortcomings of this solution.

1. We believe that there is no justifiable reason for the regulation of the finance reporting in two laws - the Accounting Act and the Auditing Act. This is because accounting is the basis, and auditing is one of the elements of the superstructure of a single financial reporting system. Auditors are professional accountants specializing in the performance of audit services, which is clearly defined by the International Education Standards for Professional Accountants IES 8. Their task is in accordance with international auditing standards to address the question of the public whether the presented financial statements, which are also compiled by professional accountants, in all material elements, present true and fair results and financial position of certain entities.

2. It eliminated the professional regulation, a key basis of financial reporting quality, where the Code of Ethics for Professional Accountants, as an ethical barrier of abuse by accountants is not mentioned.

3. It introduces the terminology for certain legal entities and entrepreneurs (micro-businesses), unknown in our legal terminology, and in line with that eliminates the application of IFRS for more than $85 \%$ of legal entities, and introduces a by-law (Ordinance on the method of recognizing, evaluating, presenting and disclosing the positions in the individual financial statements of micro and other legal entities), which drastically impairs one of the most important accounting principles - comparability of financial statements . In this way, these entities after ten years of implementation of international standards prescribe regulations which bring huge costs in terms of new forms, creating new software, new staff training of accounting entities and the like.

4. For the recognition, measurement, presentation and disclosure of position of financial statements it leaves IAS/IFRS, and introduces IFRS for SMEs, and it is not known who translates and publishes these standards (the Association of Accountants and Auditors of the Republic of Serbia has been doing this for 20 years).

5. It excluded the professional accountant, a maker of the quality of financial reporting and does not accept a large number of professional accountants, holders of professional documents, obtained under previous laws.

6. It provides unlimited possibilities for abuse, because everyone can keep books and prepare financial statements, regardless of professional expertise, 
thus drastically eroding the quality of financial reporting, position and prestige of professional accountants and the accounting profession.

7. It provides business bookkeeping and preparation of financial statements in the gray zone, because people who prepare financial statements do not sign them.

8. It formed the National Commission for Accounting, related to professional development framework, consisting of government officials, without professional accountants, which is not good.

In terms of the quality of financial reporting in the Republic of Serbia, there are two main sources of the problem:

- Lack of awareness about the importance of financial reporting,

- Lack of public accountability.

The financial statements are prepared for the tax authorities and in compliance with the legal framework. In such circumstances, the financial statements usually have only a formal significance to the Agency for Commercial Registers, and in fact are very often prepared without proper accounting basis, by people with no responsibility and professional expert credibility. All this leads to the collapse of the finance reporting to the extent that the question of trust in the financial statements appears.

In order to propose measures to improve the quality of financial reporting the process of preparation of financial statements cannot be isolated. Namely, it is necessary to examine other areas of business that are closely related to financial reporting, such as corporate management system of internal control, external audit and the business environment in general. Some of the factors that reflect the current economic and political situation in Serbia, which have an impact on the quality of financial reporting are the following:

- underdeveloped financial market (we can illustrate this with the fact that the there are only two stock exchanges - Belgrade where primarily stocks are traded and Commodity Exchange in Novi Sad),

- unfinished process of privatization of public property and the related suspicious privatization (currently, 153 companies undergoing restructuring, and 419 other companies that are not privatized are located in the portfolio of the Privatization Agency),

- low rating of our country on official published statistical ladder in terms of debt levels, credit ratings, the unemployment rate, the amount of the national average income, etc., which results in a high level of investment risk,

- extremely unfavorable business climate, ineradicable corruption,

- a high percentage of the gray economy (in the informal economy 30.1 percent of the Serbian GDP is produced, 28 percent of business entities in Serbia is engaged in the gray economy and as many as 85.3 percent of the interviewed 
economic entities indicated the existence of unfair competition within its industry, as showed in the study Gray Economy in Serbia: New Findings and Recommendations for Reform, by the Fund for the Advancement of Economics, which is funded by USAID through a grant, which was represented in the National Assembly of the Republic of Serbia on May 13th, 2013)

- inadequate workforce employed in accountancy,

- insufficient number of highly educated and professionally trained certified public accountants and auditors with extensive practical experience,

- in many entities there is no program of ethical education of employees in accounting,

- underdeveloped internal control and internal audit,

- problems in the practical application of IAS / IFRS and the lack of proper accounting for economic, legal, financial and accounting categories ,

- understanding the external audit as a legal obligation and another in a series of bureaucratic requests

- tools of financial analysis in business practice are insufficiently applied and the information capabilities of financial statements not recognized,

- there is still a belief that the financial statements and their provision of information are a business secret, which is completely absurd,

- seizure of power and defiance contribution to the development of financial reporting by only one professional organization in the country (Association of Accountants and Auditors of the Republic of Serbia ), which has been a member of IFAC since 1996, which was and still is undoubtedly one of the biggest wrong turns of the legislator (Dmitrović, Milutinovic, 2010, p. 91),

- financial reporting is heavily influenced by tax regulations. In addition to regular financial reports, business entities produce separate financial statements for the tax authorities.

Pointing to a number of factors that have an impact on the quality of financial reporting in the Republic of Serbia should not create a picture of the extremely unfavorable and hopeless situation in this area. It only indicates that the future state, professional organizations and the accounting profession in Serbia must work together and focus their activities in order to overcome the current situation and to establish realistic assumptions for a significant increase in the quality of financial reporting of the public and private sectors.

\section{Measures and Activities for Enhancing the Quality of Financial Reporting in the Republic of Serbia}

Based on pointed shortcomings of financial reporting in the Republic of Serbia, the following suggestions for improving the quality of financial reporting in the Republic of Serbia will be presented. 
1. The first step would involve the adoption of a new or amend the existing the Accounting Act because, as we pointed out, there is no justifiable reason for the regulation of financial reporting in two laws - the Accounting Act and Auditing Act. New, high quality Accounting Act must be based on a global procedure - Directive 2013-34 EU (Directive 2013/34/EU) and international standards, which is necessary for Serbia in order to create a regulated system of financial reporting. Such a law can be made only by professionally competent and ethically committed persons.

2. The development and preparation of financial statements should be done by accountants who have a professional degree in this field, which is a guarantee of their professional competence and practical experience in the aforementioned tasks. Continuing education of the accounting profession, which has been practiced so far, should be a necessity in the future, as the lifelong learning and training are the concept with confirmed success in the world and the same cannot be subject to review by state and profession.

3. State control in the field of accounting is desirable, but it must be very carefully designed so as not to return to a situation where there are para-state institutions with unclear objectives and purpose of existence, on the one hand, and national professional organizations which are stripped of all powers, on the other hand. It is necessary to avoid overlapping and intertwining of state authorities and national professional organizations and clearly delineate their activities on the development of the profession. In addition, the authorities should be prepared to surrender the bringing of accounting regulation to international professional organization which makes them lose part of their absolute legislative sovereignty.

4. I $t$ is possible to increase the level of transparency in financial reporting, maintain credibility of financial statements and accounting information by achieving acceptance, implementation of the legal framework and consistent practical application of professional regulation. The professional regulation implies Asquis communautaire with integrated EU directives relating to accounting and auditing, international accounting standards, international financial reporting standards, international auditing standards, international accounting standards for the public sector, international standards of quality control, international standards of related services, international standards of engagement, international standards of education, the IFAC Code of Ethics for professional accountants and other supporting documents, guidelines , interpretations and documents (Dmitrović, Milutinovic , 2010, p. 93).

5. The first task in improving the quality of financial reporting in Serbia could be the creation of awareness among accountants and auditors to work in the public interest and accept personal responsibility for the proper fulfillment of information needs of users of financial statements. The second task could be 
to create awareness among the owners of capital and management on the importance of high quality financial reporting and recognition of the role of financial statement audit in it. Suitable conditions for the realization of the above mentioned tasks can be created only if the state takes action to build a transparent social system, to create stabile economic growth and develop and implement successful economic policy. In addition, it is necessary to complete the started institutional construction of the entire economic and financial system as soon as possible.

The positive effects of government measures should be manifested in the protection of investors, creditors and other stakeholders who use the information in the financial statements for decision making. In such circumstances, the public confidence in financial statements could grow. The state must accept its responsibility for building the foundation of quality of financial reporting and how to identify their interests and excluded all other interests that could jeopardize the objectives of financial reporting.

\section{Conclusion}

The information contained in the financial statements are very important for many users of these statements and their economic decisions based on that information, because they are not only the basis for the assessment of what happened, but also for the assessment of future developments and trends. In order that financial statements could serve the above purpose, it is necessary that the information they contain are relevant and reliable, comparable, ascertainable, timely and understandable. This means that the financial statements should fairly and honestly present property, financial position and profitable enterprises. Only such statements can establish a key connection in the capital market, between those who possess capital and business entities where the capital is required. The quality of financial reporting should be a key factor in mitigating the risk - because we need to present information for decision-making of investors and management of a business entity. In order to increase confidence in the financial statements in Serbia, i.e. to raise the quality of financial statements, it is necessary to complete synchronization of the activities of state bodies, professional organizations, representatives of the accounting profession and users of financial statements . The paper suggests specific measures and activities to enhance the quality of financial reporting (changing legislation, building a transparent reporting system, strengthen the awareness of professional accountants and management on the importance of achieving and maintaining a high quality of financial reporting of business entities in the Republic of Serbia). 


\section{References}

Davidson, W. (1983), Handbook of modern Accounting, 3rd eddition, McGraw-Hill,

Directive 2013/34/EU is available at http://eur-lex.europa.eu/LexUriServ/ LexUriServ.do?uri=OJ:L:2013:182:0019:0076:EN:PDF, pristupljeno 15.02.2014.

Djukić, T. (2005) Mogućnosti regulisanja finansijskog izveštavanja, Ekonomske teme $5 / 2005$.

Dmitrović Šaponja, Lj., Milutinović. S., 2010, Mogućnosti unapredjenja kvaliteta finansijskog izveštavanja u Srbiji, 41. Simpozijum SRRS, Zlatibor

Elliott, B. and J. Elliott (2011), Financial Accounting and Reporting, $14^{\text {th }}$ eddition, Pearson Education Limited,

FASB, (2010): Conceptual Framework, Statement of Financial Accounting Concepts No 8, September 2010., glava 1, paragraf 2, str. 1., dostupno na internet strani: http://www.fasb.org/cs/BlobServer?blobcol=urldata\&blobtable=MungoBlobs\&b lobkey $=$ id\&blobwhere $=1175822892635 \&$ blobheader $=$ application\%2Fpdf

Fond za razvoj ekonomske nauke, 2013, Siva ekonomija u Srbiji: Novi nalazi i preporuke za reformu, dostupno na: http://www.fren.org.rs/sites/default/files/articles/ attachments/siva-ekonomija-u-srbiji-studija.pdf., pristupljeno 15.02.2014.

http://www.priv.rs/Saopstenja/10232/Licne+karte+preduzeca+kao+p.shtml, pristupljeno 15.02.2014

IASB, (2010): Project summary and feedback statement: Conceptual Framework for financial reporting,

Krstić, J., Jezdimirović, M., Đukić, T., (2013) Finansijsko računovodstvo, Ekonomski fakultet Niš

Novićević, B. (2004), Uticaj globalizacije na finansijsko izveštavanje, XXXV Simpozijum SRRS, Zlatibor

Pravilnik o načinu priznavanja, vrednovanja, prezentacije i obelodanjivanja pozicija u pojedinačnim finansijskim izveštajima mikro i drugih pravnih lica, (2013), Službeni glasnik RS, broj 118/2013.

Stojanović, R. (2011), Profesionalni računovodja - imperativ kvaliteta i finansijskog izveštavanja, Zbornik: Kvalitet finansijskog izveštavanja - izazovi, perspektive i ograničenja, SRRS, Beograd

Stojanović, R. (2012), Ciljevi i kvalitativne karakteristike finansijskih izveštaja u funkciji unapredjenja kvaliteta finansijskog izveštavanja, Računovodstvo 5-6.

Škarić Jovanović, K., (2011) Konceptualni okvir MSFI - Revizija ciljeva finansijskog izveštavanja i kvalitativnih karakteristika finansijskih izveštaja, Finrar časopis Saveza računovodja i revizora Republike Srpske.

Zakon o računovodstvu i reviziji, (2002), Službeni glasnik SRJ, broj 71/02.

Zakon o računovodstvu, (2013), Službeni glasnik RS, broj 62/2013.

Zakon o reviziji, (2013), Službeni glasnik RS, broj 62/2013. 


\title{
KVALITET FINANSIJSKOG IZVEŠTAVANJA U REPUBLICI SRBIJI
}

\begin{abstract}
Apstrakt: Kvalitetni finansijski izveštaji treba da istinito i objektivno prikažu finansijsku poziciju, rezultat poslovanja i promene finansijske pozicije određenog poslovnog entiteta. Zadovoljni korisnici finansijskih izveštaja, koji na osnovu njih donose poslovne odluke, predstavljaju najbolju potvrdu kvaliteta finansijskog izveštavanja. U radu će biti reči o konceptualnim okvirima finansijskog izveštavanja i pokušaju da se napravi jedinstven, revidiran konceptualni okvir, kao zajednički projekat FASB-a i IASB, kao i novinama koje taj okvir donosi. Takođe, u radu je prikazano trenutno stanje u pogledu kvaliteta finansijskog izveštavanja u Republici Srbiji i ukazano na neke nedostatke računovodstvene regulative na nacionalnom nivou kao preduslova kvalitetnog finansijskog izveštavanja. Na kraju, predložene su mere i aktivnosti za unapređenje kvaliteta finansijskog izveštavanja $u$ trenutnim ekonomsko-političkim uslovima u Republici Srbiji.
\end{abstract}

Ključne reči: finansijsko izveštavanje, revidirani konceptualni okvir, ciljevi izveštavanja, kvalitativne karakteristike, Republika Srbija 